\title{
Factors Influencing Organizational Performance in Hotel Sector of Nepal
}

\author{
Dhan Raj Chalise*
}

DOI: https://doi.org/10.3126/jnbs.v14i1.41496

Received on 10 June 2021

Accepted on 14 November 2021

\begin{abstract}
The present study is designed to identify the factors influencing organizational performance based on native research work carried out through field study. Adopting descriptive cum analytical research design, this study is based on primary data obtained from the hotels located inside the Kathmandu valley of Nepal through the use of a five-point Likert-type questionnaire. With the help of the random sampling technique, 130 employees working in 23 hotels in the position of executive, managerial and officer's level are taken as sample respondents. Four different variables affecting hotels' performance i.e., qualification, training and experience, administrative efficiency and location are taken as the independent variables and organizational performance as the dependent variable. Descriptive and inferential statistics have been used in this study. All the variables obtained Cronbach alpha value greater than .65, which shows the consistency on items taken for the study. The correlation analysis showed a strong positive correlation between organization performance and performance factors in the Nepalese hotel sector. Moreover, the regression analysis indicated that qualification of the employee, administrative efficiency of hotel management and training and experience provided to the employee are found strong predictors of organizational performance but the location factor was not found the determinant of organization performance in the Nepalese hotel sector. This study can further expand by adopting other variables affecting organizational performance in the hospitality sectors of Nepal.
\end{abstract}

Keywords: Hospitality sector, hotel location, performance factors, qualification

\section{INTRODUCTION}

The hotel sector of Nepal has plummeted after the hard hit by contemporary global crises. The Nepalese hospitality industry has been drastically clumped by the bash of the COVID-19 crises. In the meantime, the Nepalese hospitality industry needs self-assessment to realize the pros and cons within them and has to upraise once again (Chalise, 2017). To lift the hospitality sector, observation of internal and external organizational factors has to be analyzed (Chilla et al., 2014). Employees are the central concern for organizational performance in every organization and most

\footnotetext{
* Mr. Chalise is an Assistant Professor at Shanker Dev Campus, Faculty of Management, Tribhuvan University. Email: sgreport2dr@gmail.com 
organizations provide their attention for managing organizational performance. Employees' performance can enhance by putting attention on factors that affect the performance. This analysis can help promote internal tourism as well hospitality sector to move ahead from current financial crises. Identification of organizational performance factors provides a way forward to develop a long-term vision and mission in the hotel sector.

The hospitality sector has been experiencing a period of unexpected transformational changes after a couple of decades, which is expected to continue in the future too. It has suffered several general trends in the international community. Customers are shifting and a new type of customer has appeared. The pace of technology has changed embracing e-commerce and etourism in the new global market. Nowadays, the hospitality industry is operating under a very lively and translucent environment that results in pressures for competitive advantage. In addition, it seeks more efficient customer relations management over the systematic and effective performance of the institute. In the era of the twenty-first century, it has witnessed hasty changes in the nature and structure of global hospitality markets. Those countries having Emerging markets like Russia, China, India and the Gulf countries have provided incredible opportunities for the development of the hospitality sector (Lamba \& Dubey, 2014). The achievement of operation of the hotel industry is dependent on employee quality and the overall organizational performance linked with the handling of organizational change factors (Aksu, 2005; Agut, et al., 2003; Hai-yan \& Baum, 2006).

The present context has hovered the hotel sector in dilemma on the managerial aspect. Hotel sectors are rigid sectors for flexible organizational changes. There are many barriers to adopting new situations with ease, especially in the Nepalese hotel sector. Thus, in the meantime how organizational performance can be enhanced by the hotel sector can be a hot issue of discussion (Manoharan \& Singal, 2019). In the recent time of the shadowed economy, the Nepalese hospitality sector especially the hotel industry has suffered a lot. The economy has slowly moved on to the path of the limelight after the current descend which reveals pavement to run hotel businesses in Nepal. So, is hotel employees well trained, experienced and qualified is another issue for discussion in meantime (Fernández-Robin et al., 2019).

Recently, Nepal government is taking measures for focusing the tourist and the hospitality sector basically in terms of compression the country's aviation guidelines to align with the endorsements from the International Civil Aviation Organization (ICAO). Attempts to update its airports and create monitoring stations to advance visibility and communication remain the example in Nepal toward the improvement activities of the Nepalese government in this sector. Though, it appears uncertain that Nepal will be able to report its shortage in road networks without the dynamic participation of neighboring countries. So this study examines the effect of organizational change variables i.e., technology, culture, employee development, managing resistance to change and its effect on performance mainly in the hotel sector of Nepal. Unsuccessful administration of change may have undesirable effects on the performance of a business ensuing in loss of valued employees, output loss, active and inactive struggle, reduce ability, slower change speed adoption, failure to meet objectives of the hotels, finishing of missions behind schedule and over budget and finally, dissatisfied client may also move to other competitors (Korir, et al., 2012).

The hotel sector can again present the spark in the corporate sector of Nepal if hotels know the factors influencing organizational performance. This study provides insight into the organizational performance in the hotel sector in Nepal. The study focuses on the qualification, training and experience, administrative efficiency and location. The hotel sector can adopt new ways of achieving success through improving organizational performance. The framework used on the research work can be very useful in making the effective decision and meeting the strategic plan in the hotel sector of Nepal. In light of the above discussion, this study raised two questions, 
first: How is the status of organizational performance factors in the hotel sector of Nepal, and second: To what extent the qualification, training and experience, administrative efficiency and location determine for organizational performance indicators in Nepal? With the support of the above research questions the study aims to study on the title "Factors influencing organizational performance in the hotel sector of Nepal." More specifically the study aims to identify the organizational performance factors in the hotel sector of Nepal and to examine whether the qualification, training and experience, administrative efficiency and location determine organizational performance indicators in Nepal.

The organization dimension reflects human resource qualifications and the operations of the organization, in the notion that highly skilled work and good internal functioning are part of the environments required to accomplish at a high level. The higher the qualification of the employee, the greater their skills (Mathieu, et al., 2010). There was a relation between the skills of employees, measured by qualification and experience, and the organizational environment, dignified by the turnover of the employee. It was assumed that the more staff of these governing bodies remained in their organization, the more they can acquire experience and qualifications. In this background, subsequent hypothesis are formulated.

\section{$H_{1}$ : Qualification of hotel employees has a significant influence on organizational performance.}

Organizations can progress the quality of the existing employees by providing complete training and development package. Research and development show that investments in the training of employees in problem-solving, coordination and interpersonal relations result in valuable strong level outcomes (Barak et al., 1999). Bowra et al. (2011) found that successful organizations tend to gradually know that numerous factors contribute to the performance of an organization however human resource is the most crucial one. In addition, Tharenou et al. (2007) state that the goal of training is to improve the organization's achievement and establish a positive relationship related to the training and employee performance. Training is not useful for workers it is eventually useful for the progress of the organization. Hence the hypothesis can be expressed in the following way.

$\mathrm{H}_{2}$ : There is a significant influence of training and experience of hotel employee organizational performance.

Several studies found the contracting relationship between training and experience of hotel employees and organizational performance. There is a dearth of agreement as to what creates a valid set of organizational performance and effectiveness criteria ( $\mathrm{Au} \mathrm{1996;} \mathrm{Forbes}$ 1998; Ostroff 1992). Though several scholars focus on a single indicator, there seems to be a common agreement that many internal and external measures are desirable for an additional complete evaluation of organizations (Kim, 2004). There is a significant relationship between facilities planning efficiency and allocative efficiency of an organization, administrative efficiency and employee performance in the short run, and ultimately organizational performance (Takwate, 2018). Following the above discussion, another hypothesis can be stated as:

$\mathrm{H}_{3}$ : There is a significant impact of administrative efficiency of hotel employees on organizational performances.

The location of stable intra-organizational relations does matter and hypothesize how social capital's effect on performance is dependent upon the core or peripheral position in the institution of those individuals who are involved in stable relationships. However, such effects are greatly dependent upon the core-periphery position of such ties. It is crucial to identify that information allotment can only be improved where stable ties are present, assuming how they encourage trust between organizational members. Furthermore, maximizing the organizational stock of different talent, giving more attention to social capital and, notably, to its location in the 
organizational system can be a fruitful corresponding practice in hiring and retaining employees, which could allow organizations and groups to gain greater rewards from their existing network structures (Reagans et al., 2005). In this background, hypothesis is stated as:

\section{$\mathrm{H}_{4}$ : There is a significant influence of the location of a hotel on organizational performance.}

The structural contingency theory states that there is nothing like the best or worst structure for any organization (Yucel \& Yucel, 2016). This theory states that any organizational structure can be organized and composed through the situation prevailing in the contemporary context (Otenyo, 2018). Therefore, it is not about adopting the best structure but is about defining the course of action that guides an organization for success (Fernandez et al. 2019). With this approach, the hotel sector can provide a coherent paradigm that can help the hotel industry to go through recovery. The hotel sector having great potentiality can use structural contingency theory to underpin the recent crisis and help enhance the optimism for financial growth.

Kale (2005) states that the change realizes when 'must achieve' the expected result of the change-making decision, though the organizational change and its result is unknown. Hence, the period of transition is invited uncertainly. The confirming factor lies in the effective management of change that arises over the users of the accepted change; those who are expected to change as well in a way that explains the necessity of new thoughts (Kale, 2005). A hospitality study would cause concern to the industry on the question of the current status of hospitality management education. Of the managers interviewed by Hausman (2000), around 20 percent believed the quality was poor and that it was extra decreasing since there is a lot of stress on theory parts. In addition, they found that the quality of educators in most institutions is poor and the faculties were out of interaction with the contemporary needs of hotels. The quality of industrial training in the hotels was not up to the spot, which is the most complaint from the faculty members (Seth, 2005).

Various studies reveal that historically, managers in Japan found trained in-house within their businesses. Hospitality management programs are found absent in almost all of Japanese campuses, further, the learning for hoteliers is achieved mainly within corporations instead of in managerial education programs. Japan is a country where in-house management training has been the norm and lifetime employment as a historical practice of Japan, employees would start working at one company in their youth and remain until retirement, often focused on management grooming as such, baccalaureate-level hospitality programs have not taken a stronghold within Japan (Taylor \& Berger, 2000). Various factors can help enhance the performance of the hotel sector such as potential human resources, trained staffing and knowhow of organizational culture be some of the crucial aspects (Gyanwali \& Walsh, 2020). Based on the above review on the empirical and theoretical context on factors associated with the organizational performance the study framework has been taken as stated in Figure 1.

\section{Figure 1}

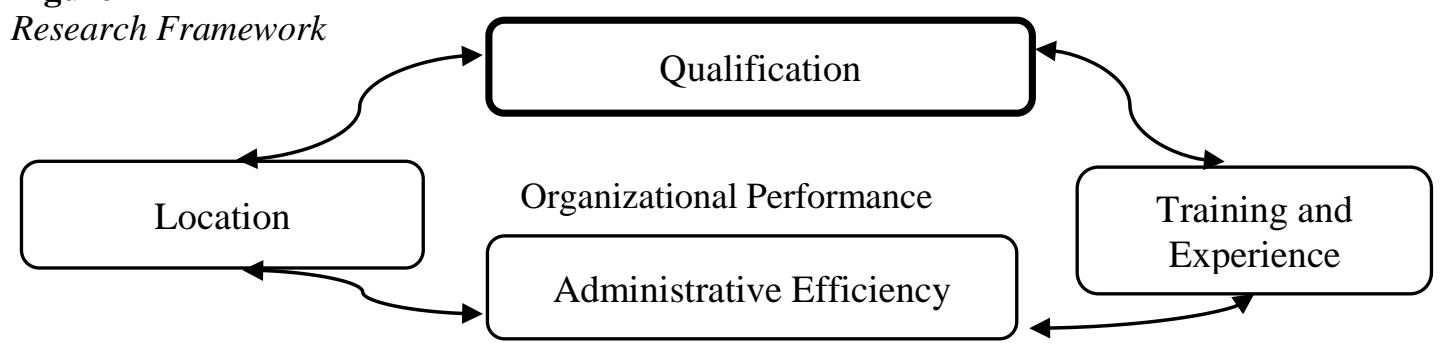

Source: Koseoglu, M. A., Putra, E. D., Yi, X., Okumus, F., \& Zhao, X. (2019).

Figure 1 shows the factors associated with determining organizational performance in hotels. Organizational performance has been taken as a dependent variable whereas qualification 
of employees, location of hotel, training and experience of the employees, administrative efficiency and location of the hotel are considered as independent variables in this study. The detailed explanation of the above conceptual framework has been explained in the following headings.

\section{Qualification of Employee}

The qualification of an employee is taken as an independent variable in this study. The qualification of employees and academics are some of the key aspects to ensure enriched performance in the organization. The hospitality sector is service-oriented sector and moral attitude is the basic component of enhancing performance in this field (Karki, 2018). A qualified employee can not only ensure performance but also can help solve the problems prevailing in the organization (Pereira et al. 2019). The hotel sector has an enormous workload on employee and employee has to be tactical to solve an array of the problem (Sthapit \& Shrestha, 2018). To measure the qualification of employees, five items measure adopted from Laskarin (2017) were taken for example, 'I understand the how-to adapt with organizational culture', 'I have the knowledge to deal with the complex situation' etc. Thus, the qualification of an employee matters a lot in the hotel sector to enhance performance.

\section{Employees Training and Experience}

Hotel is a service sector where changes in customers' needs and expectations are regarded as common challenges. In the cutting-edge corporate sector where competitiveness is a regular aspect, the hotel has to have trained and experienced employees (Chalise, 2017). Through training and experience, the employee can become more competitive and up to the standard as required by the organization. Training and experience can help enhance organizational performance (Prasanth, 2015). A trained employee can also help to develop a strategic plan and ensure proper decisionmaking in an organization (Gautam, 2015). The training and experience of hotel employees were developed with the six items as defined by McGuire, \& Bagher (2010). The items include, 'empower staff to participate in decisions affecting the organization', 'help employees overcome diversity barriers', etc.

\section{Administrative Efficiency of Hotel}

In the meantime, when the hotel sector is harshly been hit by COVID crises, a boost from the administration is needed to overcome from passing scenario (Gossling et al., 2021). Nepal being the country with the potential to grow the tourism sector has to wait for some time to enlarge the flow of tourists from a foreign country. However, in the initial period hotel sector has to focus on engaging local tourism which is possible through administrative efficiency (Poldrugovac et al., 2016). Administration need to pull the morale of employee for enhancing organizational performance in this recent time (Abdou et al., 2020). The administrative efficiency of an employee in a hotel was measured with the help of items like the organization is achieving its goal as determined, eliminating discrimination, etc., developed by McGuire, \& Bagher (2010).

\section{Location of Hotel}

Service-oriented sectors are almost dependent on customer's choices. The hotel sector, therefore, has to be choosy on the selection of location during the establishment of hotels. The location which has panoramic views and an adorable environment can easily attract customers. Similarly, hotel to enhance performance has to ease on reach (Dordevic et al. 2016). Therefore, location is the primal factor for enhancing organizational performance in the hotel sector (Puciato et al., 2017). The location of the hotel was measured with the eight items developed by (Kundu \& Contractor, 1999). For examples 'hotel transportation is important/I am satisfied with hotel transportation and 'hotel safety is important/I am satisfied with this hotel's safety. 


\section{Organizational Performance}

The hotel sectors of Nepal are currently in a period of crisis. The hospitality sector has a higher possibility of growth in tourism possibility country (Chilla et al., 2014). As there is the various natural scenic view that can mesmerize tourist all around the world. Nepal has to focus on overcoming the scattered drop of the economy. Organizational performance can be enhanced through an array of factors (Manoharan \& Singal, 2019). The measurement of Organizational performance for diverse levels of the ladder can be assessed for individuals, groups, and the whole organization level (Knies et al., 2016). An organized literature review of 213 studies existing in reputed journals or a period of 2006-2009 exposed 207 different measures used for evaluating performance (Richard et al., 2009). The major construct for measuring organizational performance found financial performance, product market performance, and shareholder return. For this study to measure the performance of hotels seven non-financial measures were used due to the lack of financial data of hotels as they were not listed on the Nepal stock exchange. The items like level of customer satisfaction, working conditions, frequency of product development, etc. were used which items were used (Suharno, et al., 2017).

\section{METHODOLOGY}

This research is quantitative. To solve the research problem and meet the objective of the research, the researcher uses primary data. The primary data were obtained by the researcher from the hotels located inside the Kathmandu valley of Nepal through the use of a structured questionnaire. Nepal's tourism industry provides 371,140 jobs (CBS, 2020). There are 1289 hotels registered as member hotels in the hotel association of Nepal (138 Star Hotels and 1151 tourist standards) and among them, about $72 \%$ are established in Kathmandu valley (HAN, 2020). 130 employees working in twenty-three different hotels were randomly selected from executive, managerial and officers level employees. The purposive sampling technique was used so that the respondent is chosen to meet the information required for the study. It is assumed that the measurement of performance indicated will be known through high-level employees in comparison to lower-level employees working in the hotel industry. The researcher uses a fivepoint Likert scale questionnaire and a quantitative method of data collection in the study. Four different variables under performance measurement indicators as the independent variable and organizational performance as the dependent variable are considered for the study framework. Under those four independent, qualification consists five items, training and experience consist four items, administrative efficiency also consists of four items and location consists six items in each variable while organizational performance consists of nine items taken for the study. All the variables obtained Cronbach alpha value greater than .65 , which shows the consistency on items taken for the study.

\section{RESULTS AND DISCUSSION}

The tabular form is used to interpret the data which is analyzed through the Likert five scale questionnaire. The researcher presents organizational performance as a dependent variable and qualification, training and experience, administrative efficiency and location as the independent variables. 


\subsection{Descriptive Analysis}

Table 1 shows the demographic information of the respondents of the study. Among the 130 respondents, the majority of the respondents i.e., about 58 percent are male. The composition of educational qualification consists highest (50\%) from bachelor level and intermediate and master level respectively by about 35 percent and 15 percent. The majority of the respondents (57 percent) are found under the married group in the hotel industry.

Table 1 also depicts the status of the respondent about positions. The majority of the respondents are from the officer level (68 percent) followed by managerial (25 percent) and executive-level (seven percent) respectively.

\section{Table 1}

Descriptive information's of the Respondents

\begin{tabular}{lll}
\hline & Frequency & Percent \\
\hline Gender & & \\
$\quad$ Male & 75 & 57.7 \\
$\quad$ Female & 55 & 42.3 \\
Education & & \\
$\quad$ Up to Intermediate & 45 & 34.6 \\
$\quad$ Bachelor & 65 & 50 \\
$\quad$ Masters and Above & 20 & 15.4 \\
Marital status & & \\
$\quad$ Single & 35 & 27 \\
$\quad$ Married & 95 & 73 \\
Position & & 68 \\
$\quad$ Officers Level & 88 & 25 \\
$\quad$ Manager Level & 32 & 7 \\
$\quad$ Executive Level & 10 & \\
\hline
\end{tabular}

Table 2 shows that all the variables under study obtained Cronbach value above 65 and shows the internal consistency of the items taken for the study. No items were deleted and found suitable and represented the variables in measuring organizational performance in the Nepalese hotel industry.

Table 2

Reliability Statistics of the items under study

\begin{tabular}{lll}
\hline Variables & Items & Cronbach \\
\hline Qualification & 5 & 0.761 \\
Training and Experience & 4 & 0.786 \\
Administrative Efficiency & 4 & 0.777 \\
Location & 6 & 0.692 \\
Organizational Performance & 9 & 0.815 \\
\hline
\end{tabular}

\subsection{Correlation Analysis}

Correlation analysis is used to determine the positive and negative correlation between the dependent variable i.e. organizational performance and independent variable i.e. qualification, training and experience, administrative efficiency and location. 
Table 3

Correlation Analysis $(N=130)$

\begin{tabular}{|c|c|c|c|c|c|c|}
\hline & & $\begin{array}{l}\text { Organizational } \\
\text { performance }\end{array}$ & Qualification & $\begin{array}{c}\text { Training } \\
\text { and } \\
\text { experience }\end{array}$ & $\begin{array}{c}\text { Administrative } \\
\text { efficiency }\end{array}$ & Location \\
\hline $\begin{array}{l}\text { Organizational } \\
\text { performance }\end{array}$ & $\begin{array}{l}\text { Pearson } \\
\text { Correlation } \\
\text { p-value }\end{array}$ & 1 & & & & \\
\hline Qualification & $\begin{array}{l}\text { Pearson } \\
\text { Correlation } \\
\text { p-value }\end{array}$ & $\begin{array}{l}.823^{* *} \\
.000\end{array}$ & 1 & & & \\
\hline $\begin{array}{l}\text { Training and } \\
\text { experience }\end{array}$ & $\begin{array}{l}\text { Pearson } \\
\text { Correlation } \\
\text { p-value }\end{array}$ & $\begin{array}{l}.817^{* *} \\
.000\end{array}$ & $\begin{array}{l}.801^{* * *} \\
.000\end{array}$ & 1 & & \\
\hline $\begin{array}{l}\text { Administrative } \\
\text { Efficiency }\end{array}$ & $\begin{array}{l}\text { Pearson } \\
\text { Correlation } \\
\text { p-value }\end{array}$ & $.703^{* *}$ & $\begin{array}{l}.659^{* *} \\
.000\end{array}$ & $\begin{array}{l}.783^{* *} \\
.000\end{array}$ & 1 & \\
\hline Location & $\begin{array}{l}\text { Pearson } \\
\text { Correlation } \\
\text { p-value }\end{array}$ & $\begin{array}{l}.756^{* *} \\
.000\end{array}$ & $\begin{array}{l}.788^{* * *} \\
.000\end{array}$ & $\begin{array}{l}.836^{* *} \\
.000\end{array}$ & $\begin{array}{l}.665^{* *} \\
.000\end{array}$ & 1 \\
\hline
\end{tabular}

**Correlation is significant at the 0.01 level (2-tailed).

The correlation coefficient between organizational performance and qualification is .823 . It means organizational performance has a positive correlation with qualification. Their corresponding p-value is 0.000 which is less than alpha 0.01 . Therefore, there is a positive relationship between organizational performance and qualification. Similarly, the correlation coefficient between organizational performance and training and experience is .817 . It means organizational performance has a positive correlation with training and experience. Their corresponding p-value is 0.000 which is less than alpha 0.01 . Therefore, there is a positive relationship between organizational performance and training and experience.

In addition, the correlation coefficient between organizational performance and administrative efficiency is .703. It means organizational performance has a positive correlation with administrative efficiency. Their corresponding p-value is 0.000 which is less than alpha 0.01 . Therefore, there is a positive relationship between organizational performance and administrative efficiency. Moreover, the correlation coefficient between organizational performance and location is .756. It means organizational performance has a positive correlation with the location. Their corresponding p-value is 0.000 which is less than alpha 0.01 . Therefore, there is a positive relationship between organizational performance and location.

\subsection{Multiple Regression}

The significant impact of independent variables on the dependent variable is tested through p-value. Independent variable qualification, training and experience, administrative efficiency and location were regressed with dependent variable organizational performance. The coefficient value and t-value are clearly explained in the analysis. 


\section{Table 4}

\section{Multiple Regression}

\begin{tabular}{lccll}
\hline Variables & Coefficient & Std. Error & $\boldsymbol{t}$-statistic & $\boldsymbol{p}$-value \\
\hline (Constant) & .460 & 1.431 & .321 & .748 \\
\hline Qualification & .450 & .082 & 5.489 & .000 \\
\hline Training and experience & .326 & .106 & 3.068 & .003 \\
\hline Administrative Efficiency & .144 & .081 & 1.771 & .009 \\
\hline Location & .069 & .093 & .740 & .461 \\
\hline$R$ - squared & 0.465 & $F$-statistic & \multicolumn{2}{c}{3.81} \\
\hline Adjusted $R$ - Squared & 0.318 & Prob. $(F$-statistic $)$ & 0002 & \\
\hline S.E. of Regression & 134.87 & Durbin-Watson Test & 2.484 & \\
\hline
\end{tabular}

Table 4 presents the value of $\mathrm{R}$ squared, $\mathrm{F}$ statistic and other relevant statistics for goodness of model fit. All the indicators of model fitness came to support the model of regression good at all. In addition, table 4 determines that the coefficient beta on qualification is positive with the coefficient beta .450 , training and experience is positive with the coefficient beta .326 , administrative efficiency is positive with the coefficient beta .144 and location is also positive with the coefficient beta .069. The t-statistics value on qualification is 5.489 and the significant level is .000 which is less than .05 . The t-statistics value on training and experience is 3.068 and the significant level is .003 which is less than .05 . The t-statistics value on administrative efficiency is 1.771 and the significant level is .009 which is less than .05 . The t-statistics value on location is .740 and the significant level is .461 which is greater than .05 . Thus, regression analysis reveals except location all the independent variables there is a significant impact on organizational performance and the other three variables are except organizational performance and location.

$\mathrm{H}_{1}$ : There is a significant relationship between organizational performance and qualification is accepted,

$\mathrm{H}_{2}$ : There is a significant relationship between organizational performance and training and experience is accepted,

$\mathrm{H}_{3}$ : There is a significant relationship between organizational performance and administrative efficiency is accepted and

$\mathrm{H}_{4}$ : There is a significant relationship between organizational performance and location could not be accepted.

\subsection{Discussion of the Findings}

The researcher is convinced with Kanje et al. (2020) that the hotel sector has to work on some influencing factors for the growth of the hotel sector. This research, therefore, helps the hotel sector to find their positives and work on those areas to overcome the financial loss that happened by the COVID-19 pandemic. This research provides a promising ground for theoretical value for the investor of the hotel sector. The theoretical aspect of this research is to enlighten the thought process of an academic expert to focus on developing corrective strategies to backtrack the hotel sector. This study revealed a positive and strong impact between organization performance and performance factors in the Nepalese hotel sector. Qualification, training and experience and administrative efficiency respectively found strong predictors of organizational performance. Location factor was not found the determinant of organization performance in the Nepalese hotel sector. 
This research is truly fruitful for the management of the hotel sector to leap the changes in the organization. The hotel sector is the sector of human capital and resource management has to emphasize enhancing factors influencing organizational performance (Banija \& Thapa, 2017). The hotel-related research can guide management to lead efficient managerial strategy which is the best part of this research. Apart from that research connects society, since many people are directly connected with the hotel industry this research can show a path for economic growth also.

\section{CONCLUSION AND IMPLICATIONS}

The analysis of factors influencing organizational performance in the hotel sector of Nepal is found to be positive and significant from correlation and multiple regression analysis. There is a positive impact of qualification, organizational performance and training and experience, and administrative efficiency on organizational performance. Due to transportation and communication technology, the location may not stand key factor of organization performance in the hotel sector in Kathmandu Valley

The value of qualification, training and experience and smooth administration can enhance performance. These similar types of results are observed in other research as well (Gossling et al., 2021). Similarly, there is a significant influence between dependent and all the independent variables as the $\mathrm{p}$-value is less than .05 . This study provides a promising ground for theoretical value for the investor of the hotel sector. Moreover, it is equally fruitful for the management of the hotel sector to leap the changes in the organization. In addition, it reveals the way to lead an efficient managerial strategy which is the best part of this research.

\section{REFERENCES}

Abdou, A. H., Hassan, T., \& El Dief, M. M. (2020). A Description of green hotel practices and their role in achieving sustainable development. Sustainability , 12, 1-20.

Agut, S., Grau, R., \& Peiró, J. M. (2003). Competency needs among managers from Spanish hotels and restaurants and their training demands. International Journal of Hospitality Management, 22(3), 281-295.

Aksu, Z. (2005). Application of bio sorption for the removal of organic pollutants: A review. Process biochemistry, 40(3-4), 997-1026.

$\mathrm{Au}, \mathrm{C}$. 1996. Rethinking organizational effectiveness: Theoretical and methodological issues in the study of organizational effectiveness for social welfare organizations. Administration in Social Work 20, 1-21.

Banija, R., \& Thapa, P. (2017). Hotel attributes influencing international tourists satisfaction and loyalty. Journal of Tourism and Hospitality , 7, 44 -61.

Central Bureau of Statistis. (2019). Report on the Nepal Labour Force Survey 2017/18. Central Bureau of Statistis, 66-67. https://nepalindata.com/media/resources/items/20/bNLFSIII_Final-Report.pdf

Chalise, D. R. (2017). Organizational change and performance in Nepalese hospitality industry. KAAV International Journal of Law, Finance \& Industrial Retaions , 5 (1), 1-11.

Chilla, H. A., Kibet, Y., \& Douglas, M. (2014). Effects of organizational culture on organizational performance in the hospitality industry. International Journal of Business and Management Invention , 3 (1), 1-13.

Dordevic, A., Zecevic, B., \& Stancic, B. H. (2016). Importance of various service types in hotelsempirical analysis. Economic Themes , 54 (3), 403-423. 
Fernández-Robin, C., Celemín-Pedroche, M. S., Santander-Astorga, A., \& Alonso-Almeid, M. D. (2019). Green practices in hospitality: A contingency approach. Sustainability , 11, 1-24.

Forbes, D. P. 1998. Measuring the unmeasurable: Empirical studies of nonprofit organization effectiveness from 1977 to 1997. Nonprofit and Voluntary Sector Quarterly 27, 183-202.

Gautam, D. K. (2015). Strategic human resource development: Shifting paradigm in Nepalese listed companies. Journal of Management , 6 (2), 55-65.

Gossling, S., Scott, D., \& Hall, M. (2021). Pandemics, tourism and global change: A rapid assessment of COVID-19. Journal of Sustainable Tourism , 29 (1), 1-20.

Gyanwali, S., \& Walsh, J. C. (2020). Influencing factors of organizational performance in Nepal airlines corporation. International Business Research, 13 (1), 268-283.

Hai-yan, K., \& Baum, T. (2006). Skills and work in the hospitality sector: The case of hotel front office employees in China. International Journal of Contemporary Hospitality Management, 18(6), 509-518. https://doi.org/10.1108/09596110610681548

Hausman, A. (2000). A multi-method investigation of consumer motivations in impulse buying behavior. Journal of Consumer Marketing, 17(5) 403-426. https://doi.org/10.1108/ 07363760010341045

Hotel Association of Nepal. (2020). List of the hotel in alphabetic order. Hotel Association of Nepal (HAN). http://www.hotelassociationnepal.org.np

Kale, S. H. (2005). Change management: Antecedents and consequences in casino CRM. UNLV Gaming Research \& Review Journal, 9(2), 5.

Kanje, P., Charles, G., Tumsifu, E., Mossberg, L., \& Andersson, T. (2020). Customer engagement and EWOM in tourism. Journal of Hospitality and Tourism Insights , 3 (3), 273-289.

Karki, G. B. (2018). A brief environmental analysis of tourism and hotel industries and their impact on Nepalese base structure. KMC Research Journal , 2(2), 59-70.

Kim, S. (2004). Individual-level factors and organizational performance in government organizations. Journal of public administration research and theory, 15(2), 245-261.

Knies, E., Jacobsen, C., \& Tummers, L. (2016). Leadership and organizational performance: State of the art and a research agenda. The Routledge Companion to Leadership, 426-440.

Korir, J., Musyoki, J., Korir, K., \& Barno, W. (2012). Determinants of consumer purchase decisions in zero rated hotels in Eldoret town. Kenya.International Journal of Business and Social Science 3(21), 158-163

Koseoglu, M. A., Putra, E. D., Yi, X. Y., \& Zhao, X. (2019). Strategic decision tools and organizational performance in the hotel industry. Journal of China Tourism Research , 15 (1), 15-32.

Kundu, S. K., \& Contractor, F. J. (1999). Country location choices of service multinationals: An empirical study of the international hotel sector. Journal of International Management, 5(4), 299-317.

Lamba, H. S., \& Dubey, S. K. (2014). Analysis of requirements for big data adoption to maximize IT business value. In 2015 4th International Conference on Reliability, Infocom Technologies and Optimization (ICRITO). Trends and Future Directions. 1-6. IEEE.

Laskarin A., M. (2017). The impact of hotel employee satisfaction on hospitability performance. Tourism and hospitality management, 23(1), 105-117. https://doi.org/10.20867/ thm.23.1.8 
Mathieu W., Thierry Z., Emmanuel B., \& Leigh R. (2010). Organizational performance of Olympic sport governing bodies: dealing with measurement and priorities, Managing Leisure, 15 (4), 279-307. https://doi.org/10.1080/13606719.2010.508672

Manoharan, A., \& Singal, M. (2019). Organizational effectiveness in hospitality: Managers perspectives. International Journal of Hospitality Management , 80, 123-125.

McGuire, D., \& Bagher, M. (2010). Diversity training in organisations: an introduction. Journal of European Industrial Training. 34(6):493-505. https://doi.org/10.1108/ 03090591011061185

Ostroff, C. 1992. The relationship between satisfaction, attitudes, and performance: An organizational level analysis. Journal of Applied Psychology 77 (6): 963-74.

Otenyo, E. (2018). Contingency theory of organizations: Global encyclopedia of public administration, public policy, and governance, African and Asian Studies, 17(4), 417-420.

Pereira de Oliveira, J., Torres, T. L., de Mello, R. D., \& Tomelin, C. (2019). Concepts of hospitality and its application in the built space: Genesis and evolution of urban hospitality in tourist Brazilians destinations. Journal of Hospitality and Tourism Insights , 3 (2), 155-170.

Poldrugovac, K., Tekavcic, M., \& Jankovic, S. (2016). Efficiency in the hotel industry: An empirical examination of the most influential factors. Economic Research, 29, 583-597.

Prasanth, S. (2015). Training and development in hotel industry. Shanlax International Journal of Management, 3(1), 27-34.

Puciato, D., Slaby, T., \& Gawlik, A. (2017). Condition of business and holiday hotels location. Barometr Regionalny, 15 (1), 77-87.

Reagans R, Argote L, \& Brooks D. (2005). Individual experience and experience working together: predicting learning rates from knowing who knows what and knowing how to work together. Management Science, 51(6), 869-881

Richard, P. J., Devinney, T. M., Yip, G. S., \& Johnson, G. (2009). Measuring organizational performance: Towards methodological best practice. Journal of management, 35(3), 718 804.

Seth, R. (2005). Tourism in India: An overview (2 Vols.). Kalpaz Publications.

Sthapit, A., \& Shrestha, B. (2018). Employee retention practices in hospitality industry in Nepal: Investigating the moderating effect of management hierarchy, age group and gender. Kelaniya Journal of Human Resource Management, 13(2), 1-22.

Suharno, P., Purwanto, K. S., \& Muzaffar, M. (2017). Factors affecting employee Performance of PT. Kiyokuni Indonesia, International Journal of Law and Management, 59 (4), 602-614.

Takwate, K. T. (2018). Planning, allocative and administrative efficiency of school facilities management as correlates of academic performance of senior secondary school students in Adamawa State, Nigeria. Budapest International Research and Critics InstituteJournal, 1(3), 114-125.

Taylor, M. S., \& Berger, F. (2000). Hotel managers' executive education in Japan: Challenges and opportunities. Cornell Hotel and Restaurant Administration Quarterly, 41(4), 84-93.

Yucel, S., \& Yucel, I. (2016). Estimating the cost of digital service delivery over clouds. In 2016 International Conference on Computational Science and Computational Intelligence (CSCI) (pp. 623-628). IEEE. 